\title{
Sex, drugs, and rock and roll
}

\section{Revisiting the lot of the first incestuous family: the biblical origins of shifting the blame on to female family members}

\author{
Ilan Kutz
}

Who seduced whom in the biblical incest story of Lot and his daughters? The answer reveals an ancient cover-up ploy that is in use to this day
Incest that involves the sexual abuse of a child by an adult family member is sadly far from rare. Exact figures elude researchers, but studies suggest that the incidence of incestuous child abuse is far too common in Western societies. ${ }^{1-5}$ "It is incest itself-and not the absence of incest-that has been universal . . . in most places at most times." ${ }^{5}$

Perhaps the first report of father-daughter incest appears in the Bible in the book of Genesis 19. The seducer this time, however, is not the father, Lot, whose wife had crystallised into a pillar of salt, but rather the Their unconventional manoeuvre, today it would be labelled "drug rape," is implicitly and partially excused by the Bible by their desire to fulfil the first divine/evolutionary decree, procreation: "Our father is old and there is no man to lie with us as is the way all over the earth" (Genesis 19, 31). Capitalising on his fondness for wine, "they got their father to drink wine on that night, and the elder one came, and lay with her father, and he knew nothing of her lying down or her rising up." The following night the scene repeats itself, this time with the younger sister, while Lot remains in his inebriated ignorant stupor. Both liaisons resulted in pregnancies. "And the older one gave birth to a boy, and she named him Moab, he is the father of the Moabites of this day. And the younger also gave birth to a boy, and she named him Ben Ami, he is the father of the Ammonites of this day" (Genesis 19, 37-38).

According to Deuteronomy (23, 4-7) the Israelites were banned from contact with these two nations: "A Moabite and an Ammonite shall not join the community of God, even a tenth generation removed shall not join the community of God forever more." I propose that it is this ban that explains the incorporation of the myth of Lot and his incestuous daughters in the Hebrew Bible. According to biblical research, the myths about Lot in Genesis and the Book of Deuteronomy were written after $600 \mathrm{BC}$, long after the events to which they refer (Lot, before $1700 \mathrm{BC}$, and Deuteronomy, before $1250 \mathrm{BC}) .^{6}$ The Israelite monotheistic biblical writers were concerned with the threat from the idol-worshipping neighbours, the Moabites and Ammonites, who were the Israelites' closest kin by intermarriage and language. I suggest that these writers incorporated the myth of Lot into the Biblidaughters, who conspire to extract their father's seed. cal text to discredit the idol worshippers. Through this carefully crafted plot, the biblical narrators confirmed the ethnic proximity of these nations to the people of Israel but at the same time cast an ancient blot of shame on their origins.

While the biblical role of the story of Lot has a plausible explanation, what explains the assignment of roles within the incest myth? How is it that father-daughter incest is universally perpetrated by the father, while in Genesis the roles are reversed?

In my view, some painters, such as Dürer (1555), Francesco (1600-46), and most strikingly Goltzius (1558-1617), suggest that the roles were not reversed, and that it was Lot who abused his daughters. In Goltzius' painting, the naked Lot is not in a deep alcoholic daze but is fully coherent and cunningly sizing up his prey, a far cry from "and he knew nothing of her lying down or her rising up" repeated after each daughter lies with him. In this painting, alcohol is not dulling his senses but probably disinhibiting his frontal lobes, which is precisely what happens to many abusive fathers when they drink.

\section{Not adding up}

Re-reading Genesis 19, this time with the hypothesis of Lot as the abusive father, unmasks certain inconsistencies in the plot and reveals additional clues to support

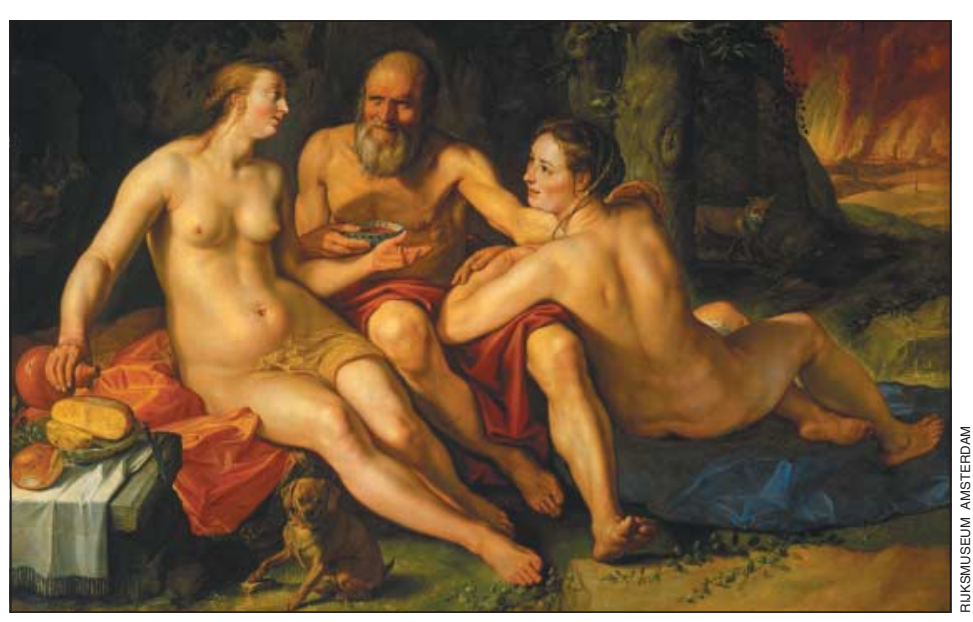

Lot and his daughters by Hendrik Goltzius

Meir Genera Hospital and Shalvatah Kfar Saba 44281,

Israel

Ilan Kutz liaison unit

Correspondence to: I Kutz

ikutz@013.net.il

BMJ 2005;331:1507-8 Psychiatric Center,

director, consultation 
his culpability. For instance, the daughters' rationalisation for their unusual, desperate action: "Our father is old, and there is no man in the land ... let us have our father drink wine and lie with him," may hold a lot of wine but does not hold much water. There were plenty of men in the land, specifically in the nearby town of Tzo'ar to which Lot had insisted on going after the Sodom disaster and from which he was later driven away. And about a day's walk away were the tents of the tribe of Lot's illustrious uncle, Abraham, who was observing the calamitous seismic activity of the destruction of Sodom from the hills surrounding the valley. And, one could argue that when Lot's daughters plotted to "make our father drunk with wine" they probably already had a fair idea of how he behaved when drunk and could count on the predictable, sexually explosive concoction of Lot mixed with alcohol. Also unlikely is the story of the double instant impregnation, with only one nightly contact for impregnating each daughter. Usually, sexual activity has to be repeated to achieve pregnancy, sometimes over many cycles. So it's much more likely that these pregnancies were the result of repeated incestuous activity.

That incest is usually repeated is supported by modern research. Once he starts, the incestuous perpetrator often continues for years. As the daughter reaches an age when she is able to resist or flee, the activity may be repeated with a younger sister. Though the profiles of incestuous families may vary, the father-perpetrator is typically an immature individual with low self esteem, while the wife-mother is depressed, helpless, or otherwise emotionally absent. The father often uses alcohol to allay his inhibitions before molesting his daughters. Herman explains why girls will allow the sexual relationship to continue to prevent family disunity. ${ }^{7}$ She also describes the terrible psychological price paid for such a breach of boundaries.

A careful read of the earlier history of Lot and his family suddenly fits this modern family dynamics grid. In the chapters preceding the destruction of Sodom, Lot is portrayed as the no-good nephew of Abraham. He causes his uncle so much grief that the patriarch demands to part ways: "Pray part from me. If to the left, then I to the right, if to the right, then I to the left" (Genesis 13, 9). Lot chooses Sodom as his residence, a town infamous for its depraved sexual practices. Early in chapter 19, we get direct evidence of Lot's perverse relationship with his daughters. After he invites to his house two strangers, who are actually the angels of God in disguise, his townsmen surround the house, demanding to exercise their specialty perversion and "sodomise" his guests. Lot steps outside the door and attempts to appease the crazed mob: "Now pray, I have two daughters who have never known a man, pray, let me bring them out to you, and you may deal with them as you like it" $(19,8)$. Even in the most far-reaching rules of hospitality, practised by the so called "primitive cultures," there is no precedent for voluntarily submitting one's daughters to gang rape.

As befitting the dynamics of an incestuous family, Lot's wife is conspicuously missing from the scene. She is mentioned only when the family flees the smoking ruined city, and she turns into a pillar of salt. Rather than the biblical misogynist view that attributes her fate to female curiosity, I see this frozen brackish crystal as a metaphor for a mother who is frozen in her salty tears. Her older daughters have just perished in the disaster, while her younger ones are left exposed to the ongoing abuse of their drunkard of a father. Was she depressed before the catastrophe? Did she develop a paralysing post-traumatic dissociation or depression? Did she kill herself, knowing she was helpless to stop the molestation of her daughters?

\section{Transference of blame}

If it was Lot who abused his daughters, why not openly place the responsibility of the incest where it belongs rather than pinning the blame on his daughters? Sadly, the cover up ploy, which the ancient biblical narrators choose, is as familiar as the act of incest itself. Abusive men have been shamelessly mouthing excuses throughout the ages. "It wasn't my fault; it was she who seduced me, walking around the house like that. Besides, I didn't do it, I couldn't have, I was too drunk." Lot may be a notorious villain and a sordid weakling, but he is still the nephew of the patriarch, who was the progenitor of the nation, and hence the noble name and family honour must be preserved. The way out of this dilemma is to shift the blame on to the women. Seduction, according to the Bible, is in their nature anyway (see under the tree of knowledge of good and evil in the garden of Eden, where Eve is blamed for seducing Adam to commit the original sin).

In patriarchal societies the practice of diverting responsibility for and hushing up incest is encoded in the Bible in the story of Lot and his daughters. Interestingly, when one examines the detailed list of forbidden incestuous relationships in the Bible, and there are many, father-daughter incest is not explicitly stated. An explicit condemnation of this practice would have been helpful to many women, such as a friend of mine, whose father abused her while whispering in her ear that "the Bible itself does not condemn this sort of thing." Freud, whose observations led him to realise the serious impact incest had on the minds of molested girls, bowed under severe pressure, some say, and transferred incest from social reality to the realm of the wishes and fantasies of Viennese damsels.

The tradition of father-daughter incest and blaming the girls is very much alive, not only in countries with patriarchy sanctioned by religion. Even in Western societies, proponents of false memory syndrome claim that victims' memories of incest are unreliable or even inserted by therapists or disgruntled spouses. These claims carry on the ancient tradition of shifting the blame away from the male perpetrator and away from the recognition that while not all recovered memories of incest are accurate most, painfully, are.

Contributor: IK is the sole contributor

Funding: None.

Competing interests: None.

Ethics approval: Not required.

1 Russel DEH. The secret trauma: incest in the lives of girls and women. Rev Ed. New York: Basic Books, 1999

Sariola H, Uutela A. The prevalence and context of incest abuse in Finland. Child Abuse Neglect 1996;20:843-50.

3 Bentovim A, Boston P, van Elburg A. Child sexual abuse-children and families referred to a treatment project and the effects of intervention. BMJ 1987;295:1453-7.

4 Carlstedt A, Forsman A, Soderstrom H. Sexual child abuse in a defined Swedish area 1993-97: a population-based survey. Arch Sex Behav 2001;30:483-93.

5 DeMause L. The universality of incest. J Psychohistory 1991:19:123-64.

6 Friedman RE. Who wrote the Bible? New York: Simon \& Schuster, 1987.

7 Herman JL. Father-daughter incest. Boston: Harvard University Press, 2000. 